\title{
Karakteristik Fisik Briket Tempurung Kelapa Menggunakan Perekat Tepung Tapioka
}

\section{(Physical Characteristic of Shells Coconut Briquette using Tapioca Flour Adhesive)}

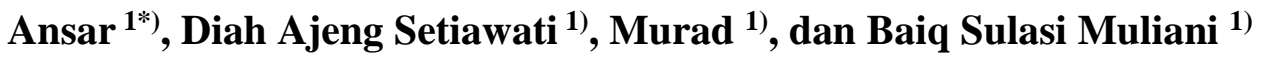 \\ 1) Program Studi Teknik Pertanian, Fakultas Teknologi Pangan dan Agroindustri Universitas Mataram \\ $\left.{ }^{*}\right)$ email korespondensi: ansar72@unram.ac.id
}

\begin{abstract}
Briquette is one of the alternative biomass fuels as a substitute for fossil energy. To produce highquality briquettes requires an effective and efficient printing press. Therefore, this study aims to obtain the best treatment in the manufacture of briquettes from coconut shells. Briquetting is made by using 4 pumping variations, namely $4,6,8$, and 12 times. The parameters observed were hardness, percentage of destruction, moisture content, and fire of briquettes. The results showed that the best coconut shell briquettes were found in pumping treatment 12 times with hardness of $27.7 \mathrm{~kg} / \mathrm{cm} 2$, percentage of destruction $18.50 \%$, moisture content $4.55 \%$ and 112.61 minute flame. While the worst quality was obtained at pumping 4 times with a hardness of $16.5 \mathrm{~kg} / \mathrm{cm} 2$, the percentage of destruction was $43.36 \%$, the moisture content was $7.92 \%$, and the flame was 111.34 minutes.
\end{abstract}

Keywords: briquette, coconut shell, pumping, water content, and flame

\begin{abstract}
ABSTRAK
Briket merupakan salah satu biomassa bahan bakar alternatif sebagai pengganti energi fosil. Untuk menghasilkan briket yang berkualitas tinggi dibutuhkan alat cetak yang efektif dan efisien. Oleh karena itu, penelitian ini bertujuan untuk mendapatkan perlakuan yang terbaik pada pembuatan briket dari tempurung kelapa. Pembuatan briket dilakukan dengan menggunakan 4 variasi pemompaan, yaitu 4, 6, 8, dan 12 kali. Parameter yang diamati adalah kekerasan, persentase kehancuran, kadar air, dan nyala api briket. Hasil penelitian menunjukkan bahwa briket tempurung kelapa yang paling baik terdapat pada perlakuan pemompaan 12 kali dengan kekerasan $27,7 \mathrm{~kg} / \mathrm{cm}^{2}$, persentase kehancuran $18,50 \%$, kadar air 4,55\% dan nyala api 112,61 menit. Sedangkan kualitas paling jelek diperoleh pada pemompaan 4 kali dengan kekerasan $16,5 \mathrm{~kg} / \mathrm{cm}^{2}$, persentase kehancuran $43,36 \%$, kadar air 7,92\%, dan nyala api 111,34 menit.
\end{abstract}

Kata Kunci: briket, tempurung kelapa, pemompaan, kadar air, dan nyala api

\section{PENDAHULUAN}

\section{Latar Belakang}

Minyak tanah yang sering digunakan sebagai sumber bahan bakar untuk kebutuhan masyarakat memperoleh subsidi dari APBN yang sangat besar yaitu mencapai 31,58 triliun per tahun (Siswanto, 2020). Jika program subsidi ini terus dijalankan pemerintah, otomatis membebani APBN. Salah satu strategi untuk mengatasi beban subsidi yang tinggi tersebut adalah menciptakan sumber bahan bakar alternatif berupa briket dari limbah tempurung kelapa.

Pembuatan briket dari limbah tempurung kelapa sebagai sumber energi panas alternatif 
merupakan pilihan yang tepat untuk mengurangi subsidi energi yang berasal dari minyak bumi. Menurut (Rindayatno \& Lewar, 2017), penggunaan briket sebagai bahan bakar lebih murah $65 \%$ jika dibandingkan dari minyak tanah, gas, dan kayu. Hal yang sama juga diungkap oleh (Patandung, 2014) bahwa bahan bakar menjadi murah jika bahan baku yang digunakan banyak tersedia dan melimpah di alam dan teknologi yang digunakan untuk pembuatannya juga sederhana.

Briket merupakan bahan bakar padat yang dapat dibuat dari limbah biomassa yang mengandung karbon dengan nilai kalor cukup tinggi dan dapat menyala dalam waktu yang lama. Beberapa peneliti sebelumnya telah mengembangkan briket dari berbagai jenis bahan baku. (Brunerova, 2019) telah mengembangkan briket dari limbah gergaji kayu dan hasilnya menunjukkan bahwa briket ini memiliki kandungan nilai kalor yang cukup tinggi untuk keperluan memasak, namun belum dijelaskan lebih lanjut tentang karakteristik fisik briket seperti kekerasan, persentase kehancuran, kadar air, dan nyala api.

Metode pembuatan briket dapat dilakukan dengan beberapa jenis, salah satunya menggunakan metode pengepresan sistem hidrolik (Patandung, 2014). Metode pengepresan memiliki kelebihan dan kekurangan. Seperti yang dijelaskan oleh (Ansar, Rahardjo, Noor, \& Rochmadi, 2014) bahwa tekanan yang terlalu tinggi pada saat pengepresan dapat mengakibatkan produk terlalu keras. Sebaliknya, tekanan yang terlalu rendah dapat mengakibatkan produk mudah hancur. Kedua karakteristik yang saling bertolak-belakang ini membutuhkan penentuan gaya pengepresan untuk menghasilkan karakteristik briket yang sesuai dengan syarat SNI.

Berdasarkan beberapa argumentasi di atas, maka sangat penting untuk dilakukan penelitian guna mengkaji karakteristik fisik briket tempurung kelapa menggunakan bahan perekat tepung tapioka sebagai salah satu sumber energi aternatif.

\section{METODOLOGI PENELITIAN}

\section{Waktu dan Tempat}

Penelitian telah dilaksanakan pada bulan Juni sampai dengan Oktober 2019 di Laboratorium Daya dan Mesin Pertanian, Fakultas Teknologi Pangan dan Agroindustri, dan Laboratorium Stuktur dan Bahan, Fakultas Teknik, Universitas Mataram.

\section{Alat dan Bahan}

Alat-alat yang digunakan dalam penelitian ini adalah mesin pres pembuat beriket sistem hidrolik, nampan, alat tumbuk, sendok, kompor, panci, ayakan mesh $20 \mathrm{~mm}$, stopwach, moisture analyzer, UTM Adventast 9. Sedangkan bahan-bahan yang digunakan adalah tempurung kelapa, air mineral, dan tepung tapioka.

\section{Prosedur Penelitian}

Penelitian ini diawali dengan mengeringkan tempurung kelapa menggunakan sinar matahari hingga diperoleh kadar air berkisar antara 20-25\%. Selanjutnya dilakukan pengarangan pada suhu $300-400^{\circ} \mathrm{C}$ (Purwanto \& Sofyan, 2014). Arang yang diperoleh dihaluskan kemudian disaring menggunakan ayakan 20 mesh. Selanjutnya arang bubuk dicampur dengan larutan tapioca kanji dengan rasio 1:3 untuk menghasilkan adonan. Adonan yang sudah tercampur rata kemudian ditimbang dengan berat masing-masing dalam satu cetakan yaitu $80 \mathrm{~g}$ dan dicetak pada mesin cetak briket (Gambar 1).

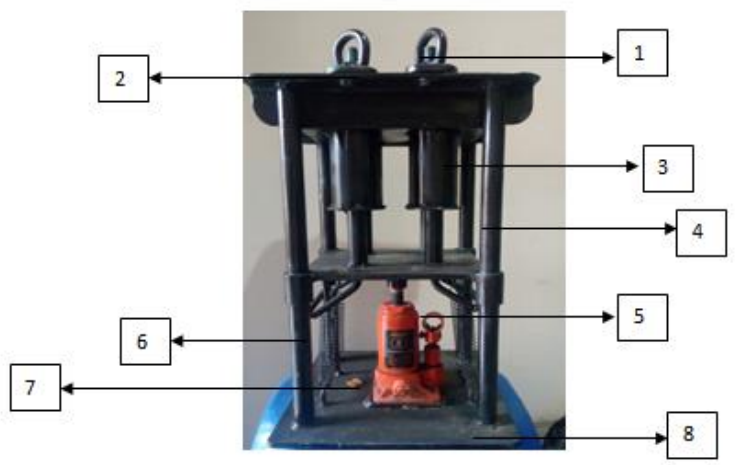

Gambar 1. Mesin cetak briket sistem hidrolik Keterangan gambar:

1. Pengunci berguna sebagai pengunci saat penutupan bahan di dalam pengempaan. 
2. Penutup kempa berguna sebagai penutup dan penahan bahan pada alat agar bahan tidak keluar pada saat dipompa.

3. Tabung berguna sebagai tempat memasukkan bahan yang akan dicetak.

4. Penyangga untuk menyangga alat pengempa briket selama pengoperasian berlangsung.

5. Tempat memasang tuas berguna untuk memasangkan tuas sebagai pemompa.

6. Pegas berfungsi menaik-turunkan bahan lebih mudah.

7. Dongkrak untuk memberikan gaya ke bawah agar pengepres menyentuh silinder yang berisi adonan briket yang akan dicetak.

8. Alas sebagai pijakan kaki alat agar tidak bergeser.

Prinsip kerja mesin pencetak briket ini menggunakan sistem hidrolik yang di lakukan dengan pemompaan. Bahan dimasukkan ke dalam tabung kemudian ditutup dan dikunci. Selanjutnya bahan di pompa dengan 4 variasi pemompaan. Setelah itu bahan dikeluarkan dan keringkan. Briket tempurung kelapa yang telah kering selanjutnya dilakukan uji kekerasan, persentase kehancuran, kadar air, dan nyala api.

Prosedur pengujian nilai kekerasan briket dilakukan dengan menggunakan metode pengujian kuat tekan dengan alat UTM Advents 9, dengan langkah sebagai berikut:

1. Briket diletakkan di atas alas uji mesin UTM Advents 9.

2. Mesin dinyalakan, sehingga pengepres perlahan-lahan menyentuh bidang permukaan briket.

3. Mesin dijalankan dengan kekuatan konstan (beban) sampai briket hancur.

4. Dicatat pembacaan beban (F) yang diberikan

5. Dilakukan perhitungan dengan persamaan:

$$
\sigma=\frac{F}{A}
$$

dimana,

$\sigma=$ Kekerasan $(\mathrm{MPa})$,

$\mathrm{F}=$ gaya $(\mathrm{N})$,

$\mathrm{A}=$ Luas permukaan $\left(\mathrm{mm}^{2)}\right.$
Persentase briket hancur adalah perbandingan antara briket hancur dengan briket padatan (\%) yang dapat dihitung persamaan:

$$
K b=\frac{b 2}{b 1} x 100 \%
$$

dengan, $\mathrm{Kb}=$ persentase briket hancur $(\%), \mathrm{b} 1$ $=$ berat awal $(\mathrm{g}), \mathrm{b} 2=$ briket hancur $(\mathrm{g})$

Kadar air awal briket diperoleh dari pengukuran menggunakan moisture analyzer, sedangkan kadar air akhir ditentukan dengan persamaan:

$$
\mathrm{Ka}_{n}=\frac{M b_{n-1}-M b_{n}}{M b_{n-1}} \times 100 \%
$$

dengan, $\mathrm{Ka}_{\mathrm{n}}=$ kadar air $(\%)$ hari ke-n, $\mathrm{Mb}_{\mathrm{n}-1}=$ berat bahan hari ke $n-1, M_{n}=$ berat bahan hari ke-n

Uji nyala api dilakukan untuk mengetahui lama waktu briket menyala dengan cara membakar briket seperti pembakaran terhadap arang. Pencatatan waktu dimulai ketika briket dinyalakan hingga briket telah menjadi abu.

\section{HASIL DAN PEMBAHASAN}

\section{Uji Kekerasan}

Kekerasan briket yang dihasilkan berkisar antara 1,65-2,77 MPa (Tabel 1). Kekerasan ini dipengaruhi oleh jumlah pemompaan yang digunakan pada saat pencetakan. Semakin banyak jumlah pemompaan, kekerasan briket juga semakin tinggi. Pemompaan dapat menyebabkan pemadatan pada volume briket, sehingga luas kontak menjadi lebih besar dan terjadi ikatan antar partikel yang lebih kuat. Hasil penelitian ini sejalan dengan data yang dilaporkan oleh (Ansar, Rahardjo, Noor, \& Rochmadi, 2014) bahwa semakin tinggi gaya pengepresan, ikatan antar partikel juga semakin padat sebagai akibat dari perubahan bentuk pada saat pengepresan, sehingga masing-masing butiran saling mengunci satu sama lain.

Tabel 1. Hasil kekerasan briket

\begin{tabular}{ccc}
\hline No. & $\begin{array}{c}\text { Jumlah } \\
\text { pemompaan }\end{array}$ & $\begin{array}{c}\text { Rata-rata kekerasan } \\
\left(\mathrm{kg} / \mathrm{cm}^{2}\right)\end{array}$ \\
\hline 1 & 4 & 16,5 \\
2 & 6 & 21,6 \\
3 & 8 & 23,1 \\
4 & 12 & 27,7 \\
\hline
\end{tabular}


Berdasarkan data pada Tabel 1 terlihat bahwa kekerasan briket tertinggi diperoleh pada pemompaan 12 kali dan terendah pada pemompaan 4 kali. Hal ini menunjukkan bahwa semakin tinggi jumlah pemompaan, maka semakin tinggi pula kekerasan briket. Hal yang sama pernah diungkap oleh (Yuliza, Nazir, \& Djalal, 2013) bahwa kekerasan briket sangat dipengaruhi oleh tekanan pemampatan. Semakin besar nilai kekerasan berarti daya tahan briket juga semakin tinggi. (Hendra \& Winarni, 2003) juga melaporkan bahwa kekuatan mekanik yang meningkat pada saat penambahan tekanan pengepresan menandakan banyaknya butiran-butiran yang menyatu, sehingga komposisi briket semakin rapat.

Nilai kekerasan briket yang diperoleh pada penelitian ini lebih kecil dari persyaratan briket arang buatan Jepang $\left(60-65 \mathrm{~kg} / \mathrm{cm}^{2}\right)$ dan Amerika $\left(62 \mathrm{~kg} / \mathrm{cm}^{2}\right)$, namun lebih besar dari persyaratan briket buatan Inggis $\left(12,7 \mathrm{~kg} / \mathrm{cm}^{2}\right)$ (Purwanto \& Sofyan, 2014). Standar Nasional Indonesia (SNI) No. 01-6235-2000 tidak mempersyaratkan nilai kekerasan suatu briket arang (SNI, 2000). Akan tetapi nilai kekerasan briket yang telah dihasilkan ini dapat mengantisipasi untuk mencegah kerusakan dalam pengepakan selama proses transportasi dan penyimpanan.

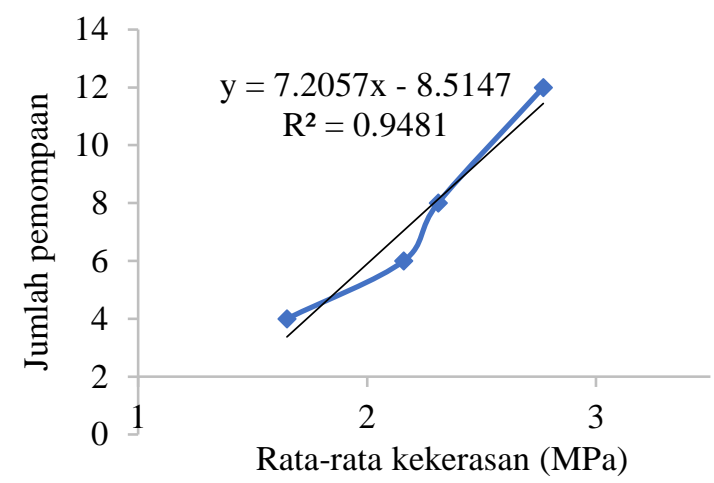

Gambar 2. Grafik hubungan antara jumlah pemompaan dan nilai kekerasan briket

Gambar 2 grafik hubungan antara jumlah pemompaan dan nilai kekerasan briket dengan koefisien diterminasi $\left(\mathrm{R}^{2}\right)=0,9481$. Hal ini menunjukkan bahwa semakin tinggi jumlah pemompaan, semakin tinggi pula kekerasan briket.

\section{Persentase Kehancuran}

Jumlah pemompaan yang tinggi mengakibatkan kekuatan mekanik briket juga semakin tinggi. Namun, penambahan jumlah pemompaan yang terlalu tinggi dapat merusak struktur bahan dasar yang mengakibatkan nilai kekuatan mekanik menjadi turun dan mengakibatkan briket menjadi rapuh.

Tabel 2. Hasil persentase kehancuran briket

\begin{tabular}{ccc}
\hline No. & $\begin{array}{c}\text { Jumlah } \\
\text { pemompaan }\end{array}$ & $\begin{array}{c}\text { Rata-rata presentase } \\
\text { kehancuran }(\%)\end{array}$ \\
\hline 1 & 4 & 43,36 \\
2 & 6 & 37,55 \\
3 & 8 & 29,68 \\
4 & 12 & 18,50 \\
\hline
\end{tabular}

Setiap variasi jumlah pemompaan didapatkan nilai kehancuran briket yang berbeda-beda (Tabel 2). Berdasarkan tabel tersebut terlihat bahwa presentase kehancuran tertinggi terdapat pada perlakuan 4 kali pemompaan yaitu sebesar $43,36 \%$ dan nilai terendah pada 12 kali pemompaan yaitu $18,50 \%$. Nilai kehancuran briket ini masih memenuhi persyaratan presentase kehancuran sesuai SNI 01-6235-2000 yaitu maksimum $20 \%$ untuk bahan bakar (Hendra \& Winarni, 2003).

Pada penelitian ini juga terungkap bahwa semakin rendah jumlah pemompaan, kerapatan bahan semakin kecil, sehingga mudah hancur dan presentase kehancurannya juga semakin tinggi. Hal ini terkait dengan jumlah partikel yang saling terikat satu sama lain pada saat pemompaan. Data ini juga mengindikasikan bahwa persentase kehancuran berbanding terbalik dengan kekerasan briket. Hasil ini sejalan dengan hasil penelitian (Waspodo \& Yang, 2009) bahwa presentase kehancuran pada briket dapat dipengaruhi oleh kandungan serat yang ada pada bahan baku yaitu tempurung kelapa. Lebih lanjut juga dijelaskan oleh (Martynis, Sundari, \& Sari, 2012) bahwa presentase kehancuran dapat diakibatkan oleh komposisi bahan baku yang mengandung abu, protein, lemak, dan karbohidrat yang dapat mengurangi ikatan antar partikel. 


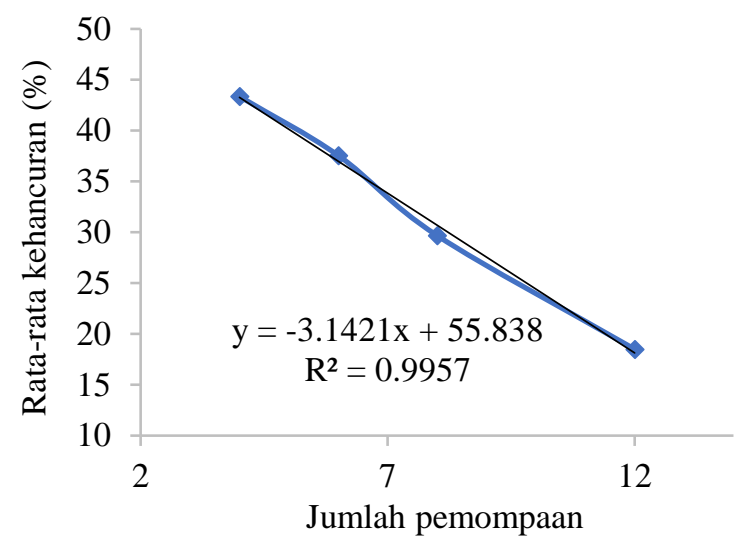

Gambar 3. Grafik hubungan antara jumlah pemompaan dan persentase kehancuran briket.

Gambar 3 menunjukkan hasil analisis regresi hubungan antara jumlah pemompaan dan persentase kehancuran pola hubungan linier yang terbalik dengan nilai $\mathrm{R}^{2}=0.9957$. Hal ini berarti bahwa jumlah pemompaan berbanding terbalik dengan persentase kehancuran briket. Fenomena seperti ini sangat umum terjadi pada pembuatan briket arang sebagaimana dilaporkan oleh (Mahdie, 2010) bahwa kekuatan mekanik briket juga dapat disebabkan oleh pencampuran bahan perekat dan bahan baku yang tidak homogeny, sehingga ikatan antar butiran masih lemah.

\section{Kadar Air}

Hasil pengukuran kadar air briket tempurung kelapa yang diperoleh berkisar antara 4,55-7,92\% (Tabel 3). Hasil kadar air ini sudah memenuhi syarat SNI No. SNI 01-62352000 yaitu maksimum 8\%. Begitu pula persyaratan kadar air untuk briket arang di Jepang berkisar antara 6,0-8,0\%, di Amerika Serikat maksimal 6,2\%, dan di Inggis maksimal 3,6\% (Hendra \& Winarni, 2003). Kadar air yang rendah ini menyebabkan briket tempurung bersifat higroskopis.

Tabel 3. Hasil pengujian kadar air briket tempurung

\begin{tabular}{ccc}
\hline No. & $\begin{array}{c}\text { Jumlah } \\
\text { pemompaan }\end{array}$ & $\begin{array}{c}\text { Rata-rata kadar air akhir } \\
(\%)\end{array}$ \\
\hline 1 & 4 & 7,92 \\
2 & 6 & 5,89 \\
3 & 8 & 5,53 \\
4 & 12 & 4,55 \\
\hline
\end{tabular}

Kadar air briket untuk setiap pemompaan mengalami penurunan yang berbeda-beda (Tabel 3). Kadar air paling rendah terdapat pada pemompan 4 kali dan tertinggi diperoleh pada pemompaan 12 kali. Kadar air briket sangat erat kaitannya dengan porositas dan higroskopis bahan setelah pemompaan. Jumlah pemompaan yang tinggi menyebabkan porositas semakin mengecil dan higroskopis bahan juga semakin berkurang, sehingga penyerapan kadar air ke dalam briket juga semakin sedikit. Hasil ini sejalan dengan penelitian (Raharjo, 2013) yang melaporkan bahwa semakin tinggi kerapatan, ronggarongga antar partikel arang semakin rapat, sehingga lebih sulit menyerap uap air dari lingkungan. (Nurhayati \& Adalina, 2007) juga melaporkan bahwa briket yang memiliki kerapatan yang rendah dapat lebih mudah menyerap udara dari sekelilingnya, menyebabkan tingginya kadar air pada briket tersebut.

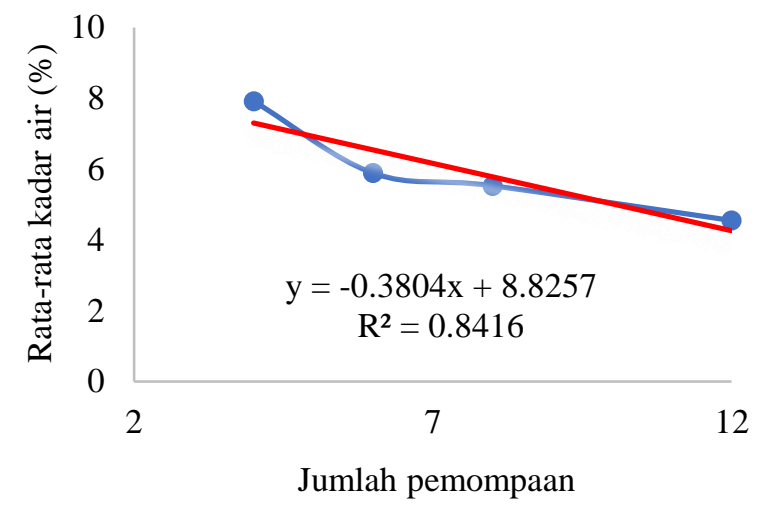

Gambar 4. Hubungan antara jumlah pemompaan dengan kadar air briket

Hasil analisis regresi antara jumlah pemompaan dengan kadar air briket menghasilkan nilai $\mathrm{R}^{2}=0,8416$. Namun hubungan yang terlihat pada Gambar 3 adalah linier terbalik. Hal ini menunjukan bahwa semakin tinggi jumlah pemompaan, maka kadar air briket semakin rendah.

\section{Uji Nyala Api}

Uji nyala api ini merupakan performansi briket terkait dengan 2 aspek yaitu waktu penyalaan dan laju pembakaran. Waktu penyalaan berkaitan dengan waktu yang diperlukan untuk menyalakan briket tempurung ini hingga muncul bara api di permukaan, sedangkan laju pembakaran adalah waktu menyala briket hingga apinya padam kemudian menjadi abu (Tabel 4). Tabel 4. Hasil uji nyala api briket tempurung 


\begin{tabular}{cccc}
\hline No. & $\begin{array}{c}\text { Jumlah } \\
\text { pemompaan }\end{array}$ & $\begin{array}{c}\text { Waktu } \\
\text { penyalaan } \\
\text { (Menit) }\end{array}$ & $\begin{array}{c}\text { Laju } \\
\text { pembakaran } \\
\text { (Menit) }\end{array}$ \\
\hline 1 & 4 & 6,16 & 111,34 \\
2 & 6 & 6,16 & 111,34 \\
3 & 8 & 6,00 & 101,46 \\
4 & 12 & 6.20 & 112,61 \\
\hline
\end{tabular}

Tabel 4 menunjukkan bahwa waktu penyalaan paling cepat terdapat pada perlakuan jumlah pemompaan 8 kali yaitu hanya 6,0 menit dan paling lama penyalaan terdapat pada pemompaan 12 kali yaitu 6,20 menit. Waktu menyala paling lama terdapat pada pemompaan 12 kali yaitu 112,61 menit dan terendah pada pemompaan 6 kali yaitu 111,34 menit. Lama menyala briket tempurung ini diduga berkaitan dengan kerapatan rongga partikel setelah pemompaan. Tekanan pemompaan yang tinggi menyebabkan kerapatan rongga semakin kecil. Rongga yang sempit ini menyebabkan partikel briket sulit terbakar dengan cepat. Fenomena ini sejalan dengan pernyataan (Sengar, Mohod, Khandetod, Patil, \& Chendake, 2012) bahwa lama menyala (laju pembakaran) dipengaruhi oleh kerapatan rongga briket, semakin kecil rongga briket, maka waktu menyala juga semakin lama. Peneliti lain juga menyimpulkan bahwa briket yang memiliki nilai kalor yang tinggi dengan kadar air yang rendah dapat menghasilkan laju pembakaran yang tinggi pula (Akowuah, Kemausuor, \& Mitchua, 2012).

\section{KESIMPULAN}

Briket tempurung kelapa paling baik diperoleh dari perlakuan pemompaan 12 kali dengan rata-rata kekerasan $27,7 \mathrm{~kg} / \mathrm{cm}^{2}$, persentase kehancuran $18,50 \%$, rata-rata kadar air 4,55\% dan laju pembakaran 112,61 menit. Sedangkan kualitas paling jelek diperoleh pada pemompaan 4 kali dengan rata-rata kekerasan $16,5 \mathrm{~kg} / \mathrm{cm}^{2}$, persentase kehancuran $43,36 \%$, rata-rata kadar air 7,92\%, dan laju pembakaran 111,34 menit.

Penyempuraan alat cetak briket ini dapat dilakukan dengan penambahan alat untuk menghitung nilai tekanan pada saat pengepresan, agar data yang dihasilkan dapat dipertanggungjawabkan secara ilmiah.

\section{DAFTAR PUSTAKA}

Akowuah, J. O., Kemausuor, F., \& Mitchua, j. S. (2012). Physico-chemical characteristics and market potential of sawdust charcoal briquette. International Journal of Energy and Environmental Engineering, 20(3), 1-6.

Ansar, Rahardjo, B., Noor, Z., \& Rochmadi. (2014). Pengaruh gaya pengepresan terhadap perubahan suhu bahan pada pembuatan tablet effervescent buah markisa. Jurnal Agritech, 26(1), 44-48. doi:10.22146/agritech.9472

Brunerova, A. (2019). Waste to briquette biofuel: a briquetting technologies. IOP Publisihing. 1. Lampung: IOP Publisher.

Hendra, D., \& Winarni. (2003). Sifat fisik dan kimia briket arang campuran limbah kayu gergajian dan sebetan kayu. Buletin Penelitian Hasil Hutan, 21(3), 211-226.

Mahdie, M. F. (2010). Briket arang dari limbah arang PT. Citra Prima Utama Banjarbaru. Jurnal Hutan Tropis, 11(2), 1-8.

Martynis, M., Sundari, E., \& Sari, E. (2012). Pembuatan biobriket dari limbah cangkang kakao. Jurnal Litbang Industri, 2(1), 31-37.

Nurhayati, T., \& Adalina, Y. (2007). Analisis teknis dan finansial produksi arang dan cuka kayu dari limbah industri penggergajian dan pemanfaatannya. Jurnal Penelitian Hasil Hutan, 27(1), 437-380.

Patandung, P. (2014). Pengaruh jumlah tepung kanji pada pembuatan briket. Jurnal Penelitian Teknologi Industri, 6(2), 95102.

Patandung, P. (2014). Pengaruh jumlah tepung kanji pada pembuatan briket tempurung pala. Jurnal Penelitian Teknologi Industri, 6(2), 95-102. 
Purwanto , D., \& Sofyan. (2014). Pengaruh suhu dan waktu pengarangan terhadap kualitas briket arang dari limbah tempurung kelapa sawit. 4(1), 29-38.

Raharjo, S. (2013). Pembuatan briket bioarang dari limbah abu ketel, jarak dan gliserin. Traksi, 3(1), 19-32.

Rindayatno, \& Lewar, D. O. (2017). Kualitas briket arang berdasarkan komposisi campuran arang kayu ulin (Eusideroxylon zwageri Teijsm \& Binn dan kayu ulin (Eusideroxylon zwageri Teijsm \& Binn. Ulin Jurnal Hutan Tropis, 1(1), 39-48.

Sengar, S. H., Mohod, A. G., Khandetod, Y. P., Patil, S. S., \& Chendake, A. D. (2012). Performance of Briquetting Machine for Briquette Fuel. International Journal of Energy Engineering, 2(1), 28-34.

Siswanto, J. (2020, Januari 19). Majalah Tempo. Retrieved from Majalah Tempo:

https://bisnis.tempo.co/read/1295252/e sdm-akan-terapkan-penyaluransubsidi-elpiji-secara-langsung

SNI. (2000). Briket arang kayu. Jakarta: SNI.

Waspodo, P., \& Yang, H. P. (2009). Pengaruh perubahan rancangan anglo dan berat jenis briket arang terhadap peningkatan efisiensi penggunaan panas. Jurnal Warta Industri Hasil Pertanian, 26(1), 1-11.

Yuliza, N., Nazir, N., \& Djalal, M. (2013). Pengaruh komposisi arang sekam padi dan arang kulit biji jarak pagar terhadap mutu briket arang. Jurnal Litbang Industri, 3(1), 21-30. 